\title{
Looking at Interactive Whiteboards through the Eyes of Pre-service Teachers
}

\author{
Mehmet Kara ${ }^{1}$, Fatih Saltan ${ }^{1}$ \\ ${ }^{1}$ Department of Computer Education \& Instructional Technology, Amasya University, Turkey \\ Correspondence: Mehmet Kara, Department of Computer Education \& Instructional Technology, Amasya University, \\ Turkey.
}

Received: October 18, 2016

doi:10.11114/jets.v4i12.1931
Accepted: November 8, $2016 \quad$ Online Published: November 16, 2016

URL: http://dx.doi.org/10.11114/jets.v4i12.1931

\begin{abstract}
There are a limited number of studies about the use of interactive whiteboards (IWBs) in higher education, specifically in teacher education. This study investigated pre-service teachers' perceptions of IWBs. The pre-service teachers involved in the study were studying in nine different teacher training programs. To achieve this goal, a quantitative survey method was employed. Participants of the study consisted of 367 pre-service teachers, 110 male and 257 female, who were studying in diverse teacher training programs. Data were collected through the "Interactive Whiteboard Student Perception Scale for University Students". The instrument consists of 18 items and three factors. Data regarding the participants' demographics and perceived level of technology competence were also collected. The data were analyzed using Pearson correlation and ANOVA statistical analysis. Confirmatory Factor Analysis (CFA) was also conducted to prove the construct validity of the instrument with a large sample. The result of CFA indicated appropriate fit indices for the instrument with three factors. The perceptions of pre-service teachers about the use of IWB were found as positive and high. Pre-service ICT and Physical Education (PE) teachers had the highest mean scores regarding the use of IWB in their courses. Post Hoc analysis indicated a significant difference relying on the department. The results also indicated that there is a significant mean difference between second and third grade pre-service teachers in favor of third grade pre-service teachers. A significant correlation was found between pre-service teachers' perceptions about the use of IWBs and their perceived technology competence.
\end{abstract}

Keywords: interactive whiteboards, pre-service teachers, teacher training programs

\section{Introduction}

Rapid developments in technology have a continuous impact on all levels of education, from kindergarten to university. Instructional activities, methods, tools, and even the appearance of today's classrooms have changed as a result of the use of technology in education. Interactive Whiteboards (IWBs) are one of the tools that play a role in this transformation. After the entrance of computers and projection devices into classrooms, today IWBs have started to take their place. This has especially occurred at the elementary and high school levels as the result of the huge investments in educational technology by governments and private schools. According to the British Educational Communications and Technology Agency (BECTA) (2003), an IWB is a touch sensitive board working with a computer and a projector device. However, today, the new generation IWB does not need a projection device since it has its own computer module and monitor. Some benefits of IWB are that it saves time by allowing teachers to access web and other resources quickly (Walker,2003); increases interactivity in the classroom (Widener, Greene, \& Gérard, 1999); and provides an opportunity for teachers to use instructional materials again (Glover \& Miller, 2001). Like many countries, in Turkey, the Ministry of National Education (MoNE) has started to implement a revolutionary project called Improving Opportunities and Technology in Education Movement (FATIH) and made huge investments. In this project, the ministry intends to equip every classroom in every school, from kindergarten to high school, with an IWB. This project undoubtedly has impacts on higher education. It has become common to use IWBs in most of the Education faculties. There are many studies in the literature indicating that IWB increases students' motivation, interaction, and learning (Armstrong, Barnes, Sutherland, Curran, Mills, \& Thompson, 2005; Wood \& Ashfield, 2008; Schuck \& Kearney, 2007; Swan, Schenker, \& Kratcoski, 2008). However, the focus of the most of the research studies in the literature is on K12 education (Digregorio \& Sobel-Lojeski, 2010). There are a limited number of research studies about the use of IWB in higher education (Demirli \&Türel, 2012; Schroeder, 2007) and further research is needed regarding 
higher education, especially regarding teacher training programs, since teacher training plays a key role in the successful integration of technology into schools (Guzman \& Nussbaum, 2009). Türel (2011) conducted a study to investigate the perceptions of pre-service teachers about the IWB use in their courses by collecting data from 110 pre-service teachers, 78 of whom were from the ICT department. He administered a survey that he had developed, which includes "Perceived ease of use and usefulness", "contribution to learning", and "interest and motivation" factors. In this study, he reported that the students had a positive perception about the use of IWB in their classes and that they thought IWB makes the learning process more enjoyable and effective.

In a study with 293 pre-service Arabic language teachers, Ishtaiwa and Shana (2011) distributed a questionnaire to the pre-service Arabic teachers and conducted interviews with them after their school experience. The study results revealed that pre-service teachers have positive perceptions about the impact of IWB as a teaching and learning tool. Akbaş and Pektaş (2011) conducted a study to investigate the impact of IWB use on student achievement. 33 Pre-service science teachers were divided into 2 groups: an experimental group, for which IWB was the independent variable, and a control group. The results showed that, although the mean score of the experimental group was higher than that of the control group, there was no significant difference between the groups. The study also showed that IWB use encouraged student participation by increasing student enthusiasm. In Divaharan and Koh's (2010) study, pre-service teachers were able to use IWBs to plan and implement lessons as teachers. They assessed the effectiveness of an IWB integration module. In a study by Campbell and Kent (2010), the IWB implementation programs of two Australian universities were examined to investigate the needs of pre-service teachers to integrate IWB into their teaching. In his study with 44 senior pre-service mathematics teachers, Hsieh (2011) used a self-constructed survey to collect data about their attitudes toward teaching by using IWB. The study revealed that their attitude toward IWB as a teaching tool is moderate. In a recently conducted study, Mata, Lazar, and Lazar (2016) investigated the effect of higher education level (undergraduate, master, or doctoral) on students' attitudes toward IWB in terms of some IWB attitude factors. According to this study, the attitudes of students studying in engineering, education, science and letters departments change depending on their level (in favor of master and doctoral students).

In addition, further review of the literature on IWB use in education indicated that the studies about IWB usage in education were mainly conducted to investigate k12 teachers' acceptance and use of IWB (Tosuntas, Karadag, \& Orhan, 2015), IWB perceptions (Lai, 2010), and faculty members' opinions (Al-Qirim,2011; Demirli\&Türel, 2011). According to Mata, Lazar, and Lazar (2016), most previous studies were experimental studies and there is a need for questionnaire-based studies focusing more on IWB usage in higher education settings.

\subsection{Purposes of the study}

The purpose of this study was to investigate how pre-service teachers who were studying in different teacher training programs perceived IWBs and to determine whether there is a correlation between pre-service teachers' perceptions of IWBs and their perceived technology competence. A secondary objective was to prove the construct validity of the instrument with a larger sample than the one in its development study. The following research questions were addressed:

1. What are the perceptions of pre-service teachers about the use of IWBs in their courses?

2. Do these perceptions differ significantly with regard to their respective teacher training programs, grade levels, and pre-service teachers' perceived technology competency?

\section{Method}

In this study, surveys were conducted in a quantitative method design to investigate pre-service teachers' perceptions of IWBs and to investigate the correlation between pre-service teachers' perceptions of IWBs and their perceived technology competence. The survey method is considered as the best method for educational purposes in order to get a lot of information from the population members (Fraenkel \& Wallen, 2006). Specifically, the survey method was used to explore participants" "characteristics, opinions, attitudes, and previous experiences" (Leedy \& Ormroad ,2005,p.183).

\subsection{Sample}

Participants of the study consisted of 367 pre-service teachers, 110 male and 257 female, who were studying in a variety of teacher training programs, including Elementary Mathematics Education, Elementary Science Education, Early Childhood Education, Social Science Education, Classroom Teaching, ICT, Literature Education and Physical Education. The number of the female participants was much higher than the number of male ones since there are more female students enrolled in the teacher training programs. The participants voluntarily participated in the study. The cluster sampling method was used. The pre-service teachers were selected from the ones enrolled in courses in which IWB is actively used as a teaching and learning tool. The frequency and percentages of the participants are presented in Table 1. 


\subsection{Instrument}

In order to collect data about the pre-service teachers' perceptions of IWBs, the "Interactive Whiteboard Student Perception Scale for University Students", developed by Türel (2011), was used. The reliability of the instrument was provided with .916 Cronbach's Alpha coefficient. The scale consists of 18 items and three factors, which are "perceived ease of use and usefulness"; "contribution to learning"; and "interest and motivation". The items are answered on a 5-point Likert scale from strongly disagree to strongly agree. Data about the participants' demographics and perceived level of technology competence were also collected. Participants rated their level of technology competence by selecting from options ranging from 1 to 5, where 1 indicates "Not competent", 2 indicates "Somewhat Competent", 3 indicates "Uncertain", 4 indicates "Competent", and 5 indicates "Highly Competent".

\subsection{Data Analysis}

Firstly, Confirmatory Factor Analysis (CFA) was conducted using LISREL software to prove the construct validity of the instrument based on the data collected. Next, descriptive analysis, Analysis of Variance (ANOVA), and Pearson correlation was conducted to examine pre-service teachers' perceptions of IWBs and to investigate the correlation between pre-service teachers' perceptions of IWBs and their perceived technology competence. SPSS 20 software was used for all of these statistical procedures.

Table 1. The frequency and percentages of the participants according to the departments

\begin{tabular}{lll}
\hline Departments & Frequency & Percentage \\
\hline Physical Education and Sports (PES) & 32 & 8.7 \\
Information and Communication Technology (ICT) & 35 & 9.5 \\
Elementary Science Education (ESE) & 70 & 19.1 \\
Elementary Mathematics Education (EME) & 63 & 17.2 \\
Early Childhood Education (ECE) & 32 & 8.7 \\
Psychological Counseling and Guidance (PCG) & 51 & 13.9 \\
Classroom Teaching (CT) & 42 & 11.4 \\
Social Studies Education (SSE) & 20 & 5.4 \\
Turkish Language Education (TLE) & 22 & 6.0 \\
Total & 367 & 100.0 \\
\hline
\end{tabular}

\section{Results}

The results are presented in the following three sections: Confirmatory Factor Analysis, ANOVA and Pearson correlation analysis.

\subsection{The Results of Confirmatory Factor Analysis}

Confirmatory Factor Analysis (CFA) was conducted using LISREL with a larger sample ( $N=367)$ than the one in the development study of the instrument by Türel (2011) to provide evidence about how well the previously proposed model fits the observed variables. In Figure 1 and Figure 2, F1, F2, and F3 represent the factors of the scale, namely, perceived ease of use; contribution to learning; and interest and motivation, respectively. The indicators from A1 to A18 represent variables in the scale.

In CFA, the $\mathrm{T}$ values were first analyzed to check how well the factors in the model explain the observed variables. If $\mathrm{T}$ values are greater than 1.96 and 2.56, then the parameter values are significant at .05 and .01 levels, respectively (Çokluk, Şekercioğlu, \& Büyüköztürk, 2010). As indicated in Figure 1, the T values regarding how well the factors in the model explain the observed variables are statistically significant at .01 level of significance.

Secondly, the error variances of the indicators and the $\mathrm{p}$ value, which gives information about the significance of the difference between the expected and the observed covariance matrixes (Çokluk et al., 2010), were analyzed using the standardized solution path diagram. As seen in Figure 2, the error variances of the indicators are quite low. The $p$ value in the model is significant at the .01 level. However, it is quite normal and tolerable for the $\mathrm{p}$ value to be significant because of the sample size (Çokluk et al., 2010).

When the error variances of the observed variables in Figure 2 are examined, it is seen that all variables have low error variances. Therefore, it is appropriate for those variables to take part in the model. 


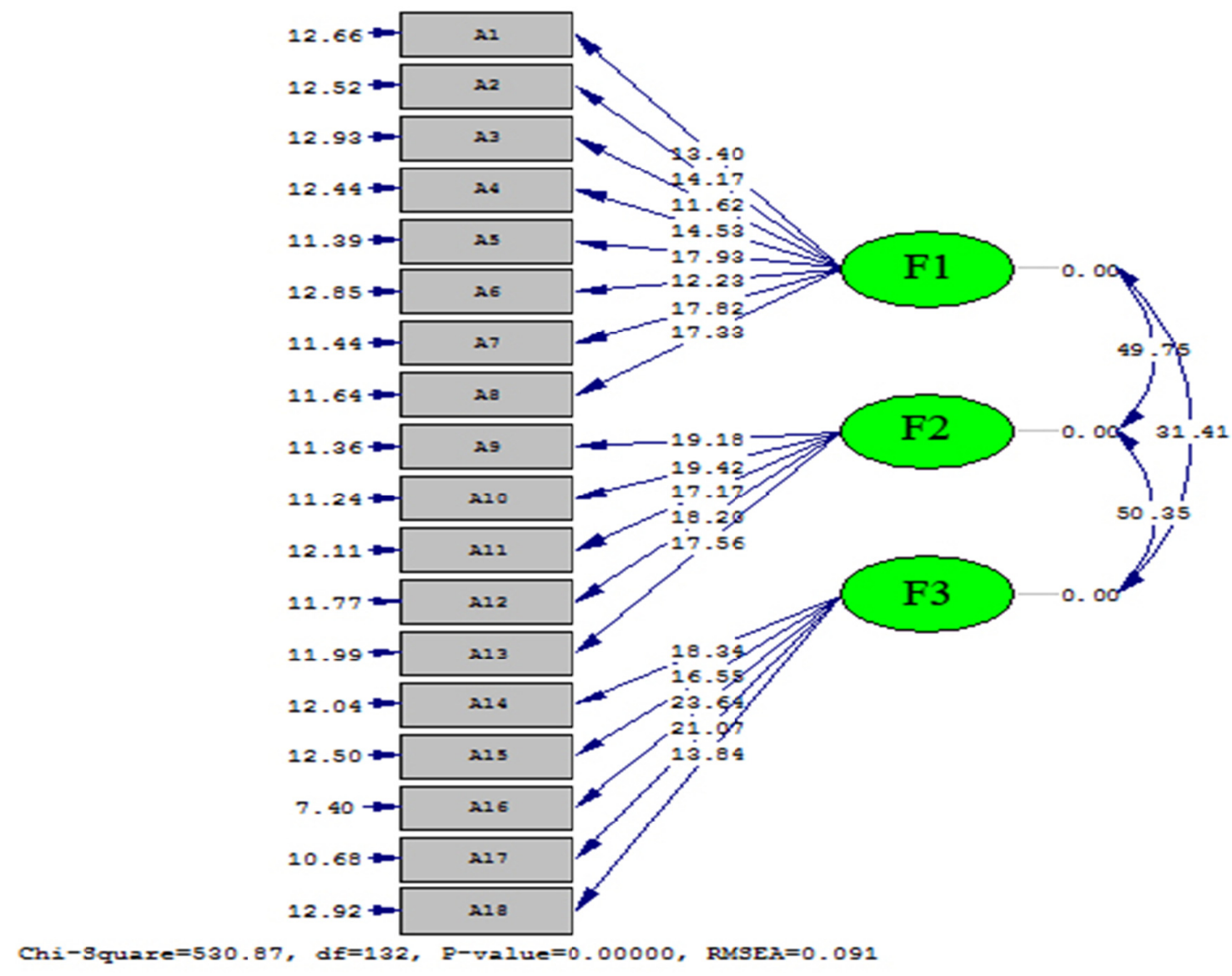

Figure 1. The Path Diagram of T values

The $\chi^{2}$ statistic for model fit is used in CFA with Degrees of Freedom (df) and if $\chi 2 / \mathrm{df}$ is less than 3 and 5 , then the model has a perfect and moderate fit with the observed data, respectively (Kline, 2005). As shown in Figure 2 , $\chi 2$ equals 530.87 and df equals 132. Hence, $\chi 2 / \mathrm{df}$ equals 4.02. This analysis shows a model fit at a moderate level since $\chi 2 / \mathrm{df}$ is less than 5. Since there is no absolute rule for the goodness of model fit, other model fit indices are still needed to be checked since each of them evaluates the goodness of the model fit from different aspects (Hooper, Coughlan, \& Muller, 2008).

When the Root Mean Square Residual (RMR) and Standardized Root Mean Square Residual (SRMR) indices were examined, it was seen that RMR equals .047 and SRMR equals .052. The RMR index shows a perfect model fit since it is less than .05 and SRMR index shows acceptable model fit since it is greater than .05 and less than .08 (Brown, 2006). The final model fit indices provided by CFA are Non-Normed Fit Index (NNFI) and Comparative Fit Index (CFI). According to Hu and Bentler (1999), if the values of NNFI and CFI are greater than .95, then these indices show perfect model fit. The values of NNFI and CFI indexes provided by CFA indicates perfect model fit since they are .97 and .98 , respectively.

According to the results of CFA, there is enough evidence to conclude that the scale items are clustered in three sub-dimensions based on the data collected from pre-service teachers as appropriate with the model, and the results provided by CFA generally show appropriate model fit indices. Thus, the CFA conducted in this study provides evidence for the construct validity of "The Interactive Whiteboard Evaluation Survey for University Students". 


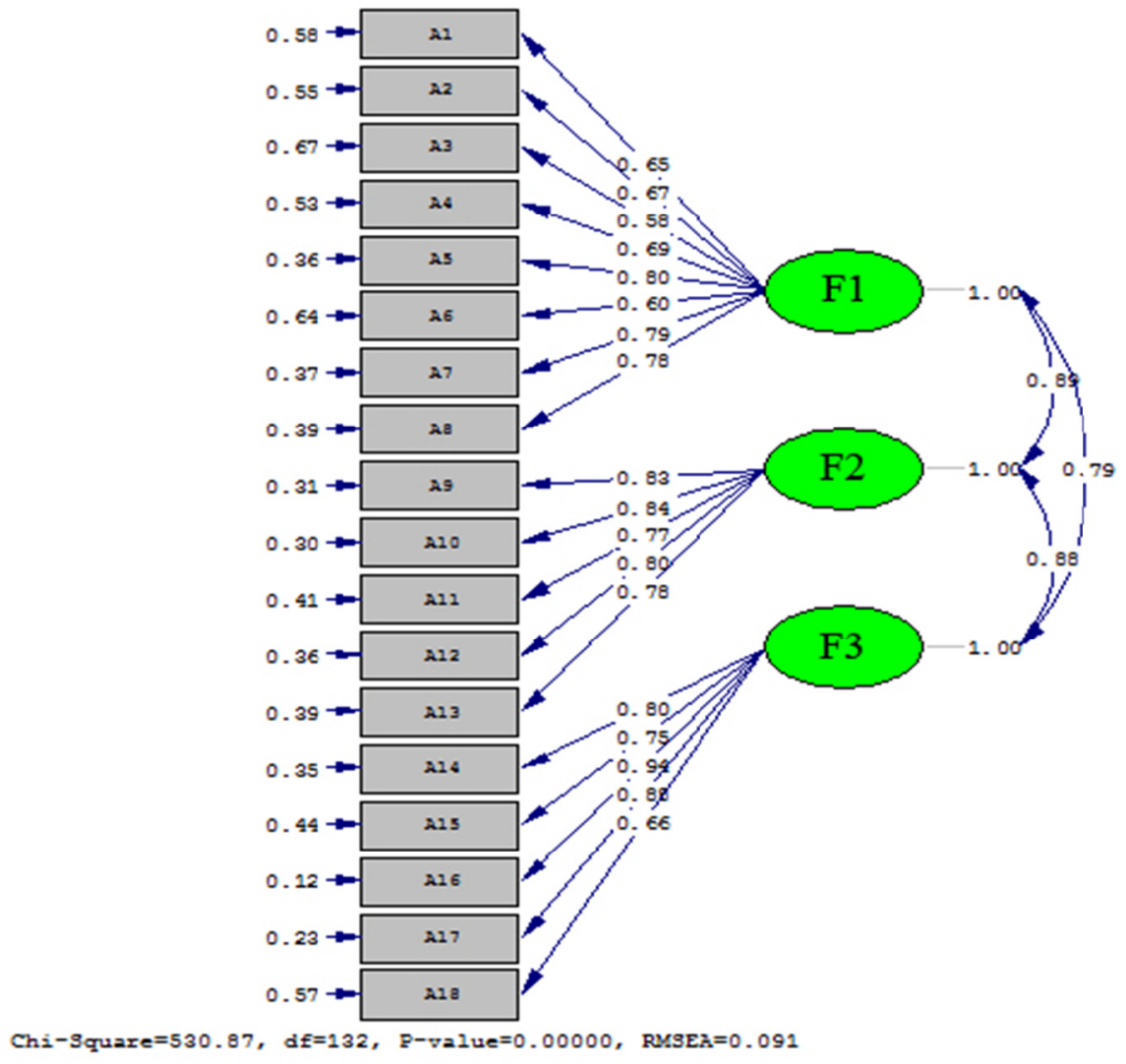

Figure 2. The Path Diagram of Standardized Solution

\subsection{The Results of ANOVA}

The perceptions of pre-service teachers about the use of IWB in their courses were positive and high. In Table 2, where A1-A18 indicates scale items, the mean and standard deviations of each item in the scale are shown below as descriptive statistics.

As shown in Table 2, Item 2, which states, "I think it is necessary for my teacher to use technology (Computer, the internet, and so on) in classes", has the highest score with 4.28. In other words, pre-service teachers strongly support the use of technology in their courses. According to item 1, which also has a higher score, pre-service teachers believe that IWB is a useful tool for their learning. Item 6 , which is "IWB is useful for the effective use of projection device and computer together", is another remarkable item that has a higher score. These three items reveal that pre-service teachers have a strong belief that IWB is a useful and practical device as a teaching and learning tool in their courses.

Table 2. The perceptions of Pre-service teachers regarding IWB Use in Their Courses

\begin{tabular}{cccc}
\hline Items & $\mathrm{N}$ & Mean & Std. Deviation \\
\hline A1 & 367 & 4.14 & .871 \\
A2 & 367 & 4.29 & .837 \\
A3 & 367 & 3.42 & 1.073 \\
A4 & 367 & 3.94 & .923 \\
A5 & 367 & 3.83 & .929 \\
A6 & 367 & 4.08 & .902 \\
A7 & 367 & 3.74 & .941 \\
A8 & 367 & 3.69 & .978 \\
A9 & 367 & 3.56 & .942 \\
A10 & 367 & 3.46 & .940 \\
A11 & 367 & 3.51 & .943 \\
A12 & 367 & 3.49 & .946 \\
A13 & 367 & 3.80 & .923 \\
A14 & 367 & 3.49 & 1.035 \\
A15 & 367 & 3.45 & .970 \\
A16 & 367 & 3.61 & .943 \\
A17 & 367 & 3.52 & .983 \\
A18 & 367 & 2.76 & 1.139 \\
Total & 367 & & \\
\hline
\end{tabular}

In general, participants have an approximate perceptions scores with the mean scores ranging from 3.42 to 3.94 except 
item 18, which is "I am impatiently waiting the time my teacher will start to use IWB", which has 2.76 mean score. This might be the result of the one-year use of IWB in their courses. Because this is a sufficient duration for removing novelty effect, IWB may have become an ordinary technology for them.

The perceptions of the participants in terms of departments are presented in Table 3. According to Table 3, ICT and PES departments have the highest mean scores regarding the use of IWB in their courses. It is also remarkable that these two departments have the highest perceived technology competence. This is an expected result considering that there is a significant correlation between pre-service teachers' perceived technology competence and their perceptions about the use of IWB in their classes as indicated in Table 7. For this reason, it can be considered that pre-service teachers' technology competency is related to their perceptions about the use of IWB in their courses as learning tools.

ANOVA was conducted to determine whether there is a significant difference between the departments in terms of their perceptions about IWB use in their courses. A significant mean difference was found between some departments at the .05 significance level (see Table 4).

Table 3. The perceptions of the participants about IWB use in terms of departments

\begin{tabular}{llll}
\hline Departments & & & Std. Deviation \\
\hline Physical Education (PES) & $\mathrm{N}$ & Mean & .742 \\
Information and Communication Technology (ICT) & 32 & 3.97 & .526 \\
Elementary Science Education (ESE) & 35 & 4.03 & .730 \\
Elementary Mathematics Education (EME) & 70 & 3.45 & .746 \\
Early Childhood Education (ECE) & 63 & 3.51 & .687 \\
Psychological Counseling and Guidance (PCG) & 32 & 3.56 & .594 \\
Classroom Teaching (CT) & 51 & 3.58 & .659 \\
Social Studies Education (SSE) & 42 & 3.79 & .785 \\
Turkish Language Education (TLE) & 20 & 3.75 & .524 \\
Total & 22 & 3.63 & .700 \\
\hline
\end{tabular}

Post Hoc analysis was conducted to determine between which departments there is a significant mean difference. Post Hoc analysis showed that there is a significant difference between PES and ESE departments $(p=.012)$ in favor of the ESE department; ICT and ESE departments $(\mathrm{p}=.002)$ in favor of the ICT department; and ICT and EME departments $(\mathrm{p}$ $=.010$ ) in favor of the ICT department at .05 level of significance. Table 4 shows ANOVA results about whether there is a significant mean difference between the departments.

Table 4. ANOVA Results for the Departments

\begin{tabular}{llllll}
\hline & Sum of Squares & $\mathrm{df}$ & Mean Square & F & Sig. \\
\hline Between Groups & 13.838 & 8 & 1.730 & 3.745 & .000 \\
Within Groups & 165.356 & 358 & .462 & & \\
Total & 179.194 & 366 & & & \\
\hline
\end{tabular}

The effect of participants' grade levels on their perception was also explored. All grade levels participating in this study have approximate mean scores in terms of IWB use in their courses ranging from 3.50 to 3.79 (see Table 5).

Table 5. Descriptive Statistics about the Participants According to Their Grade Levels

\begin{tabular}{lccc}
\hline Grade Level & $\mathrm{N}$ & Mean & Std. Deviation \\
\hline 2. Grade & 120 & 3.50 & .742 \\
3. Grade & 147 & 3.79 & .642 \\
4. Grade & 100 & 3.64 & .696 \\
Total & 367 & 3.65 & .700 \\
\hline
\end{tabular}

ANOVA was applied to determine whether there is a significant mean difference between the grade levels in terms of their perceptions about the use of IWB in their courses. A significant difference was found between the grade levels with $\mathrm{p}=.004$ at .05 level of significance. Post Hoc analysis was conducted to determine between which grade levels there are significant differences. The results indicated that there is a significant mean difference between second and third grade pre-service teachers with $\mathrm{p}=.003$ in favor of third grade pre-service teachers at .05 level of significance; $\mathrm{F}$ $(2,364)=5.592, \mathrm{p}=.004$ (see Table 6$)$.

\subsection{The Results of Pearson Correlation Analysis}

Pearson correlation analysis was applied to determine whether there is a correlation between pre-service teachers' perceptions about the use of IWB in their courses and their perceived technology competencies. 
Table 6. ANOVA Results About whether there is a Significant Mean Difference between the Grade Levels

\begin{tabular}{llllll}
\hline & Sum of Squares & df & Mean Square & F & Sig. \\
\hline Between Groups & 5.342 & 2 & 2.671 & 5.592 & .004 \\
Within Groups & 173.852 & 364 & .478 & & \\
Total & 179.194 & 366 & & & \\
\hline
\end{tabular}

As seen in Table 7, a significant correlation was found between pre-service teachers' perceptions about the use of IWB in their courses and their technology competence as perceived by them with $p=.00$ at .01 level of significance; $r=.254$, $\mathrm{N}=367, \mathrm{p}<.05$. This means that as technology competences of pre-service teachers increase, their perception scores about the use of IWB in their courses increase.

Table 7. Pearson Correlation Analysis Results

\begin{tabular}{llll}
\hline & & $\begin{array}{l}\text { Technology } \\
\text { Competence }\end{array}$ & $\begin{array}{l}\text { Perception of } \\
\text { IWB }\end{array}$ \\
\hline \multirow{3}{*}{ Technology Competence } & Pearson Correlation & 1 & .254 \\
& Sig. (2-tailed) & & .000 \\
& $\mathrm{~N}$ & 367 & 367 \\
\hline
\end{tabular}

\section{Discussion and Conclusion}

This study first provided evidence for the construct validity of "The Interactive Whiteboard Student Perception Scale" (Türel, 2011) with a larger sample than the one in its development study. The model fit indices provided by CFA generally show good and perfect model fits and this valid and reliable scale can be used in the future studies to collect data about the perceptions of university students about IWB use in their courses.

The results showed that pre-service teachers enrolled in the courses in which IWB is actively used as a teaching and learning tool have positive perceptions about IWB. This result is similar to the findings of the study conducted by Türel (2011). They have approximately the same perceptions about all items and factors in the scale. It is commonly accepted in the literature that IWB increases students' motivation, interaction, and learning in K12 education (Armstrong et al., 2005; Wood \& Ashfield, 2008; Schuck \& Kearney, 2007; Swan et al., 2008). Similarly, the descriptive results of this study indicated that IWB can be used as an effective tool in the processes of teaching and learning in teacher training programs in terms of ease of use and usefulness, contribution to learning, and interest and motivation, as it is in other levels of education. Therefore, it is suggested that IWB should be prevalently and actively used in teaching and learning in teacher training programs for pre-service teachers' motivation and learning as well as their professional development.

It was also an important finding that there is a significant correlation between pre-service teachers' perceptions about use of IWB in their courses and their perceived technology competency. This finding implies that increasing technology competencies of pre-service teachers will increase their perceptions about IWB use for their learning and will probably affect their use of IWB in their professional career as future teachers.

According to the results of this study regarding IWB perceptions of pre-service teachers in terms of their departments, there are significant differences between some departments, namely, between PES and ESE, between ICT and ESE, and between ICT and EME, and the grade levels in terms of perceptions scores about the use of IWB in their courses. However, generally the means of their perception scores about IWB use are approximate to each other. The reason behind the significant difference between these departments might be the instructors' knowledge and skills about the use of IWB. Instructor confidence in IWB use is a factor that affects student perceptions about IWB usage, since it affects pedagogy and interaction in classrooms (Digregorio \& Sobel-Lojeski, 2010). According to Measday (2005), instructor access to suitable materials and professional support is insufficient for effective IWB use in their teaching. Similarly, there is a poor support for the instructors' professional and continuous development about IWB use in their classrooms (Jones \& Vincent, 2010).Therefore, trainings and continuous pedagogical and technical support for IWB use are required for university level instructors to efficiently use IWB in their teaching.

It is suggested that instructor competencies, roles, and professional development for the use and integration of IWB in higher education and the other factors that affect pre-service-teachers' perceptions about the use of IWB as learning tools are required to be investigated in future studies. It is also suggested that systematic research about the use of IWB in teacher training programs and higher education in general are needed to make more reliable generalizations with a larger sample about the common and active use of IWB in higher education institutions.

\section{References}

Akbaş, O., \& Pektaş, H., M. (2011). The effects of using an interactive whiteboard on the academic achievement of university students. Asia-Pacific Forum on Science Learning and Teaching, 12(2), 1-13.

Al-Qirim, N. (2011). Determinants of interactive white board success in teaching in higher education institutions. Computers \& Education, 56(3), 827-838. http://dx.doi.org/10.1016/j.compedu.2010.10.024 
Armstrong, V., Barnes, S., Sutherland, R., Curran, S., Mills, S., \& Thompson, I. (2005). Collaborative research methodology for investigating teaching and learning: The use of interactive whiteboard technology. Educational Review, 57(4), 457-469. http://dx.doi.org/10.1080/00131910500279551

BECTA (2003b). What the research says about interactive whiteboards. The British Educational Communications and Technology Agency, Coventry, England.

Brown, T. A. (2006). Confirmatory Factor Analysis for applied research. New York: Guilford Press

Campbell, C., \& Kent, P. (2010). Using interactive whiteboards in pre-service teacher education: Examples from two Australian universities, Australasian Journal of Educational Technology, 26(Special issue, 4), 447-463.

Çokluk, Ö., Şekercioğlu, G., \& Büyüköztürk, Ş. (2010).Sosyal bilimler için çok değişkenli istatistik. (1st ed.). Ankara: PegemAkademi.

Demirli, C., \& Türel, Y. K. (2012) Interactive Whiteboards in Higher Education: Instructors First Im-pressions. Eurasian Journal of Educational Research, 49, 199-214.

Digregorio, P., \& Sobel-Lojeski, K. (2010). The effects of interactive whiteboards (IWB) on studentperformance and learning:a literature review. Educational Technology Systems, 38(3), 255-312. http://dx.doi.org/10.2190/ET.38.3.b

Divaharan, S., \&Koh, J. H. L (2010). Learning as students to become better teachers: pre-service teachers' IWB learning experience, Australasian Journal of Educational Technology, 26(Special issue, 4), 553-570.

Fraenkel, R. J., \& Wallen, E. N. (2006). How to Design and Evaluate Research In Education. Mc Graw Hill.

Glover, D., \& Miller, D. (2001). Running with technology: the pedagogic impact of the large-scale introduction of interactive whiteboards in one secondary school. Journal of Information Technology for Teacher Education, 10(3), 257-276. http://dx.doi.org/10.1080/14759390100200115

Guzman, A., \& Nussbaum, M. (2009). Teaching competencies for technology integration in the classroom. Journal of Computer Assisted Learning, 25(5), 453-469. http://dx.doi.org/10.1111/j.1365-2729.2009.00322.x

Hooper, D., Coughlan, J. \& Mullen, M. (2008). Structural Equation Modeling: Guidelines for determining model fit. The Electronic Journal of Business Research Methods, 6(1), 53-60.

Hsieh, K. (2011). Preservice teachers' attitudes and opinions towards interactive whiteboards and e-textbooks. Advances in Computer Science, Environment, Ecoinformatics, and Education - International Conference (Wuhan, China, August 21-22, 2011), 362-366. http://dx.doi.org/10.1007/978-3-642-23339-5_66

Hu, L. T., \& Bentler, P. M. (1999). Cutoff criteria for fit indexes in covariance structure analysis: Conventional criteria versus new alternatives. Structural equation modeling: a multidisciplinary journal, 6(1), 1-55. http://dx.doi.org/10.1080/10705519909540118

Ishtaiwa, F. F., \& Shana, Z. (2011). The use of interactive whiteboard (IWB) by pre-service teachers to enhance Arabic language teaching and learning. Learning and Teaching in Higher Education: Gulf Perspectives, 8(2).

Jones, A., \& Vincent, J. (2010). Collegial mentoring for effective whole schoolprofessional development in the use of IWBtechnologies . Australian Journal of Educational Technology, 20(4), 477-493.

Kline, R. B. (2005). Principles and practice of structural equation modeling. (Second Edition). NY: Guilford Publications, Inc.

Lai, H. J. (2010). Secondary school teachers' perceptions of interactive whiteboard training workshops: A case study from Taiwan. Australasian journal of educational technology, 26(4). http://dx.doi.org/10.14742/ajet.1069

Leedy, P. D., \& Ormrod, J. E. (2005). Practical research. NY: Pearson Education Ltd.

Mata, L., Lazar, G., \& Lazar, I. (2016). Effects of study levels on students' attitudes towards interactive whiteboards in higher education. Computers in Human Behavior, 54, 278-289. http://dx.doi.org/10.1016/j.chb.2015.07.044

Measday, B. (2005). So you've got an interactive whiteboard! Now what? Research Grants Report 2005. Department of Education and Children's Services, South Australia.

Schroeder, R. (2007). Active learning with interactive whiteboards: A literature review and a case study for college freshmen. Communications in Information Literacy, 1(2), 64-73.

Schuck, S., \& Kearney, M. (2007). Exploring pedagogy with interactive whiteboards: A case study of six schools. NSW Department of Education and, Sydney. Retrieved from https://opus.lib.uts.edu.au/handle/10453/12239

Swan, K., Schenker, J., \& Kratcoski, A. (2008). The effects of the use of Interactive Whiteboards on Student Achievement. Proceedings of World Conference on Educational Multimedia, Hypermedia and Telecommunications, 2008, 
3290-3297.

Tosuntaş, Ş. B., Karadağ, E., \& Orhan, S. (2015). The factors affecting acceptance and use of interactive whiteboard within the scope of FATIH project: A structural equation model based on the Unified Theory of acceptance and use of technology. Computers \& Education, 81, 169-178. http://dx.doi.org/10.1016/j.compedu.2014.10.009

Türel, Y. K. (2011). An interactive whiteboard evaluation survey for university students: Validity and reliability analyses, e-Journal of New World Sciences Academy Education Sciences, 6(2), 1894-1903.

Walker, D. (2003). Quality at the dockside. TES Online. 66-67.

Widener, J., Greene, M., \& Gérard, F. (1999). Using smart board in foreign language classes. Proceedings of Society for Information Technology \& Teacher Education International Conference 1999 (pp. 1268-1273).

Wood, R., \& Ashfield, J., (2008). The use of the interactive whiteboard for creative teaching and learning in literacy and mathematics: A case study. British Journal of Educational Technology, 39(1), 84-96.

This work is licensed under a Creative Commons Attribution 3.0 License. 